\title{
Target Needs in Writing Essay Material Based on Brainwriting Strategy
}

\author{
Dini Fitriani, Yumna Rasyid, Ratna Dewanti \\ \{dinifitriani_lt16s3@mahasiswa.unj.ac.id, yumna.rasyid@unj.ac.id, rdewanti@unj.ac.id\} \\ Universitas Negeri Jakarta, Indonesia
}

\begin{abstract}
Teaching material for writing an essay that accordance with the target needs is very important to give to the user, this is an effort to improve the user's ability to write an essay. Based on this matter, this study aims to develop teaching materials for writing an English essay that is appropriate to the target audience and their needs, namely by developing English essay writing skills in the teaching materials. This will be characterized by brainwriting strategies. The method used in this study is research and development $(\mathrm{R} \& \mathrm{D})$ which is focused on the analysis of the user needs by interviewing students and lectures within the English education program, STKIP Kusuma Negara Jakarta. The result of this study was to find out what the needs of people using teaching material products, to assist in writing an English essay based on brainwriting strategies were.
\end{abstract}

Keywords: Target needs, writing essay, teaching material, brainwriting strategy.

\section{Introduction}

One of the successes of learning can be achieved from the comfort of learners using teaching materials. We as educators need to be creative to give the best to our students, for example, what was done in research conducted by Dessy (2016) were to improve writing skills, "it takes several times to do the exercises repeatedly until the target for success in writing skills is achieved.[1] To improve writing skill, in this study creative steps are needed. This study also includes using a met cognitive strategy in writing learning. Based on that, researchers are interested in making creative endeavors by making teaching materials based on the needs of users who were targeted by users and lecturers at a university in Jakarta. The teaching material referred to in this study is, teaching writing an English essay. Based on the gap that arises in the current learning is the use of teaching materials that are not in accordance with user needs so that the learning outcomes are not in accordance with the learning targets, one of which is teaching the material to write English essays given to fifth-semester students. [2]

Writing an essay in English is one of the topics in writing which is usually used only by learning the material from essays taken from the internet. In addition, essay writing material is also usually taken from several books that users perceive as not in accordance with their needs, so they feel bored and not motivated to master what they are learning. This is in line with the research conducted by Amir which states that the problems that occur in essay writing skills are due to a sense of self-distrust and feeling bored will express ideas or ideas on writing.[3] After getting some information about the gaps that occur in writing English essay in the field, the author was inspired to develop teaching material for writing essays compiled with one of the strategies devoted to writing skills, namely brainwriting strategies.

In learning, needs must be given the treatment, for example in the research conducted by Arini. Her research to improve essay writing skills, researchers used a method that is giving treatment to students by using Quantum Learning With Mind Mapping strategy.[4] Where the results of this research showed to 
be positive, namely there was always a significant increase in each cycle of the study. However, there are statements in the research that was examined in the study, namely the strategies used in the teaching process, this study was used in the making of teaching material.

This study on teaching material focused on analyzing the targeted needs within English essay writing. With the data of these needs generated, the data can be used as a reference for researchers to develop teaching materials for writing essays in English based on these brain writing strategies, at a later stage.

\section{Literature Review}

Teaching material leads to everything that is used by lecturers and students to facilitate language learning to improve language knowledge and experience, for example, essay writing skills. While the development of teaching material is what is done by writers, instructors or students to provide input sources of various experiences designed to improve language learning. In addition, teaching materials need to be developed to meet the needs and desires of students, and also to meet the needs of teachers. [5] Johnson stated the stages in developing teaching material which consisted of three stages, namely: 1) designing, 2) developing, and 3) disseminating teaching material. Then, revise it to improve and refine the teaching material.

In the essence of writing, Hyland said that writing is a way to convey and express feelings through various experiences. From the author to the reader by using written language.[6] In line with Burton and King (2004) in Steven and Katheleen said that in his research most writing learning processes involve repetitive writing that focuses on experiences or negative emotional feelings such as traumatic events and personal problems.[7]

Writing skills are complex skills and sometimes quite difficult to teach, acquisition of mastery is not just grammar but also concepts and parts of the mental assessment. Learning to write coherent and effective texts is one of difficulty and is protracted, this occurs in the process of the research conducted by Ronald T, respondents who are in their research find it difficult to produce coherent and effective writing because of the formation of ideas that often not well organized.[8] Writing requires a good process as was done in the research of Teressa Limpo and Rui A. Which provides a process of writing to respondents involving four cognitive processes: planning processes that set rhetorical goals, which lead to an idea or ideas to be poured; translating processes that transform ideas into linguistic forms; transcription process that use spelling and handwriting (or typing) to externalize the language in written text; and revise the process to monitor, evaluate, and change the intended written text.[9]

The same writing process was also carried out by Jannake Van Der Loo DKK in his research, namely the main cognitive activities, which are planning (generating ideas, organizing information and goal setting), translating (placing ideas into language), reviewing (evaluating and revising texts) and monitoring (decide when to move from process to process). The author must pay attention to all these components, often all at once.[10]

It can be said that this principle is an activity in which the author pours his: ideas, opinions, experiences, and ideas into linguistic forms by using writing rules such as: content, grammar, mechanics, organizing ideas, and vocabulary to be easily understood by the reader, but active writing is not as easy as we see it. Writing requires variations of the writing component itself.

Writing in English is the most important skill as students must communicate with each other as members who are recognized within a community. The author does not only need to know the rules and conventions of writing but also must have a recognizable identity - supported by their language and rhetoric. competence - to participate in various academic writing practices. In this regard, there are studies conducted by Yu-Chin Sun and Yu-Jung Chan that examine how blogs, interactive and collaborative features help academic graduate students process academic writing knowledge and understand their identity as writers.[11] The results of this study indicate that blogging activities not only 
encourage students to actively and reflectively engage in sharing knowledge and developing various strategies to overcome the difficulties encountered in the learning process.

Brainwriting also called individual brainstorming. It's a method for generating ideas quickly by asking participants to write their ideas on paper or online and change the ideas in writing.[12] Brainwriting is not yet a common technique for generating ideas but has several advantages over brainstorming where people put their ideas in groups. One advantage is that it blocks the effects found in brainstorming, for example, understanding, evaluation and the competition for time spent talking decreases when people write their ideas privately.

Brainwriting is easier than brainstorming because it does not require an experienced facilitator almost all writing sessions are done with confidence and that produces good writing.

Brainwriting, which is defined as an alternative brainstorming technique used to create content, tries to encourage more equal participation in groups. This is also in line with what was done by Devi Hermasari and Yan Mujianto who made brainwriting as one of the strategies that tested the effectiveness of writing learning whose research results showed the effectiveness of writing learning using a brainwriting strategy.[13]

In contrast to the research conducted by the author, brainwriting strategies are used to prepare teaching material for writing essays in English, while effectiveness or impact is taken from the use of teaching materials compiled with a new writing strategy. This brainwriting strategy is also designed to generate more ideas in a short time. During the process, students are allowed to write new ideas, combine other ideas, adopt new ideas, modify ideas into alternative approaches, and add ideas. Silent students get more benefits using this technique, in this way they have the opportunity to express ideas through written media.[13]

In writing learning, strategies or strategies are needed that can facilitate student's learning in the process and also facilitate lecturers in delivering material to students because learning in the second language is very complex so it is important to give good treatment.

In this case, the brainwriting strategy is an alternative strategy that can be utilized in the process of learning to write English.[12] In this study, brainwriting strategies are used as a basis for developing teaching materials for writing essays in English. Brainwriting strategy is a strategy to devote ideas on a subject matter that is done in writing. In accordance with its function, brainwriting strategies can motivate students to come up with many ideas for writing. [14]This can be the reason that brainwriting strategies can be used as alternative strategies in learning English essay writing. Besides the ability to improve the student's skill in essay writing. The student able to write in every kind of writing, such as a book, novel, and other kinds of writing. More importantly, it is the student's interest to write more.

\section{Research Method}

The method used in this study is a mix method research with research and development $(R \& D)$ that focuses on preliminary studies of the target needs of English essay writing teaching material in the fifth semester on subtopic writing three courses. The data taken at the focus of this study is by interviewing several samples taken randomly, samples which are students and lecturers. Interviews of several students were transcribed by researchers in a statement based on the results of the interview. The datasets of this research are accessible at https://osf.io/daucb

\subsection{Place and Time of the research}

This research was conducted at STKIP Kusuma Negara Jakarta which is located in Cijantung -Jakarta. As a place for collecting initial data, an analysis of six existing study programs was needed. Data collection in this study was gathered via interviewing several students and lecturers about teaching materials for writing essays at STKIP Kusuma Negara Jakata. The time for research into the needs 
analysis was carried out for one month, namely in July 2018. The datasets of this research are accessible at https://osf.io/daucb

\subsection{Respondents}

Respondents taken in this study were respondents for interviews originating from samples taken from eight students consisting of two men and four women. Participants in this study were randomly drawn on an English education program at STKIP Kusuma Negara Jakata. Observed in this study are the conditions and needs of students related to teaching materials in writing essays in English. The questions asked are based on basic criteria that will be used in the teaching material, namely for the brainwriting strategy.

\section{Results}

In the review of the needs of the material according to the target needs, which include: 1). Teaching material needed in English essay writing skills, 2). The desired learning situation inside grade 3). Learning assignments needed by students [15]

\subsection{Teaching material needed in English essay writing skills}

The lecturer material presentation is not equipped with learning objectives and indicators; b) Presentation Material. According to the lecturer informant, the presentation book and the slide material forms did not include learning objectives, but have included indicators to be achieved. There are books that have been written, but not used because they are too complicated to use. This is in comparison with the principle of teaching and learning as suggested by Richard (2001) Further revealing the various principles of developing teaching materials, namely: 1). The material must have a strong influence, 2). The material must be able to help facilitate learners 3 ). The material must be able to make learners more confident 4). The material taught must be relevant and useful, 5). Learners must get important points to be taught, 6). The material must be able to give learners the opportunity to use language to achieve communication objectives, 7). The material must guarantee learners to get positive benefits, 8). The material must be able to accommodate differences in learning styles, 9). The material must be able to guarantee that learners have different attitudes, 10). The material must provide an opportunity to think at the beginning of learning, 11). The material must provide feedback opportunities. [16] Based on the results of interviews with students, students want essay writing material in the teaching material to be accompanied by clear examples with topics that are easily understood by students. Students want material that is short but clear. The datasets of this research are accessible at https://osf.io/daucb

\subsection{The desired learning situation inside grade}

Current responses from student informants on English essay writing teaching materials used are: (1) the material provided is only material presentations from lecturers which are slides or power point tools (PPT) This material content is too general and there are no written instructions or clear essays. Students have difficulty pouring ideas when asked to write essays. Students are also not motivated to learn more and continue their studies. This causes weak English essay writing skills. and this is similar to the results of interviews from lecturers. This is because there is not much time given to students because essays are only the subject matter in writing three courses. and this is the basis for the desire of students and lecturers to create learning that is comfortable, confident and given sufficient time to study essay. This is 
in line with the research conducted by the Munir Sirajur (2016) whose students want a comfortable, not too formal and not too much learning situation, and this can be created through teaching materials that are in accordance with the needs of students and lecturers. [5] The datasets of this research are accessible at https://osf.io/daucb

\subsection{Learning assignments needed by students}

The desired form of a learning task is an assignment whose writing topic is free, meaning the topic is determined by the students' knowledge. The lecturer is expected not to provide topics that are only based on the knowledge of the lecturer, but the lecturer must also consider the student's knowledge of the topic to be determined as a task. This is so the ideas of students can be poured easily and so that they are able to write essays well. The datasets of this research are accessible at https://osf.io/daucb

\section{Conclusions}

Based on the results of interviews with 10 samples of students in the English education study program at STKIP Kususma Negara Jakarta, when viewed from the needs of students, it is very good when teaching material for English essay writing is created with a brainwriting strategy. Well fulfilled, so that students can improve their skills in writing an English essay.

\section{References}

[1] D. Wardiah.: Increasing the the Ability Writing Short Stories Through Metacognitive Strategies, vol. 2, no. 1, pp. 92-101, (2016)

[2] Y. Ka.: The development $\mathrm{t}$ of a new ins trumen nt to asse ess met acogni itive str rategy knowle $\mathrm{k}$ edge abou ut acad demic $\mathrm{w}$ writing and its s relatio on to se ulated $\mathrm{w}$ writing $\mathrm{g}$ and writing $\mathrm{w}$ perf forman ce," J. Writ. Res., vol. 9, no. 1, p. 62, (2017)

[3] A. Mahshanian, A. R. Eslami, and S. Ketabi.: Raters' Fatigue and Their Comments During Scoring Writing Essays: a Case of Iranian Efl Learners, Indones. J. Appl. Linguist., vol. 7, no. 2, p. 64, (2017)

[4] N. W. Arini, N. Ketut, and D. Tristiantari.: Essay Writing Through Quantum Learning With Mind Mapping Strategy, vol. 6, no. 2, pp. 150-156, (2017)

[5] S. Munir.: Pengembangan \{Materi\} \{Ajar\} \{Bahasa\} \{Inggris $\}$ untuk $\{$ Agen $\}$ TTravel $\}$ ( $\{$ Sebuah $\}\{$ Kajian $\}\{$ English $\}$ for $\{$ Occupational $\}$ PPurposes $\})$, Ragam, vol. 14, no. 3, pp. 260-274, (2014)

[6] K. Hyland, Genre and Second Language Writing. New York: Camridge University Press, (2003)

[7] Toefper Walker.: Lette ers of Gratitud de : Imp proving g Wel 1-Being g throu gh Exp pressive e Writin ng, J. Writ. Res., vol. 1, no. 3, p. 182, (2009)

[8] Ronald T. Kellogg, "training writing skills : A cognitive developmenntal perspective," J. Writ. Res., vol. 1, pp. 1-26, (2008)

[9] T. Limpo and R. A. Alves.: Relaating Beliefs in Writing Skill Mallleability to Writing Perform mance : The Mediating Role of Achievement ficacy Goals and Self-Eff, J. Writ. Res., vol. 2, no. 9, p. 98, (2017) 
[10] Jannake Vander Loo.: Learning How to Write an Academic Text: The Effect of Instructional Method and Writing Preference on Academic Writing Performance, J. Writ. Res., vol. 9, no. 2, p. 300, (2017)

[11] Y. Chang and Y. Sun.: Blogging to learn: Becoming Efl academic writers, Lang. Learn. Technol., vol. 16, no. 1, pp. 43-61, (2012)

[12] C. Wilson, branstorming and beyond, First. Morgan Kaufmann, (2013)

[13] Y. M. Devi Hermasari.: the Effectiveness of Online Brainwriting and Brainstorming Techniques in Teaching Writing To, English Educ. J., vol. 5, no. 2, pp. 28-34, (2015)

[14] T. H. E. Effectiveness et al.: the Effectiveness of Online Brainwriting and Brainstorming Techniques in Teaching Writing To, English Educ. J., vol. 5, no. 2, pp. 28-34, (2015)

[15] I.S.P.Nation and John Macalister, Language curriculum design, First edit. new York and London: routledge, (2010)

[16] T. jack C. Richards Rodgers, S. Theodore, M. Jo, and S. John.: approach and methods in language teaching. New York: Camridge University Press, (2001) 